DOI: https://doi.org/10.47405/mjssh.v7i1.1251

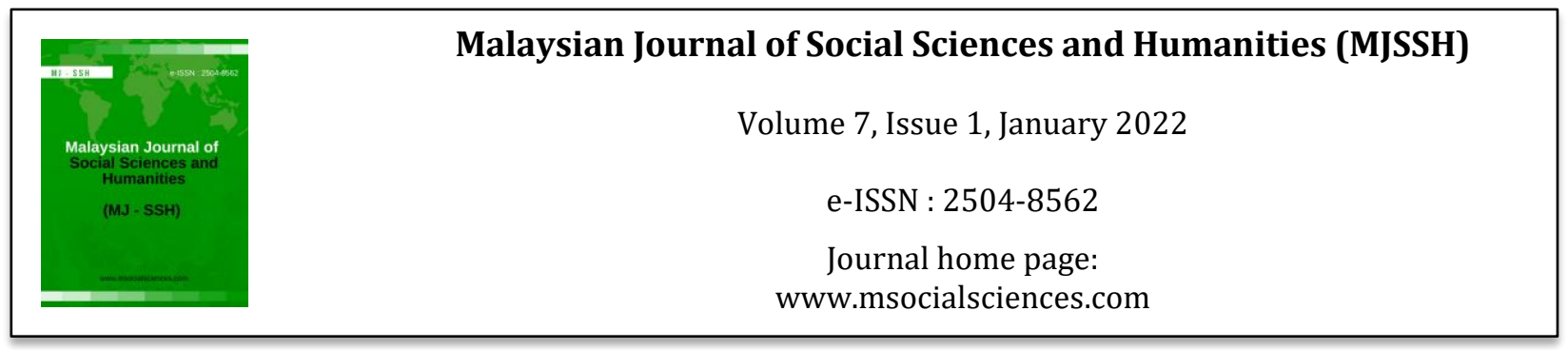

\title{
Pengetahuan dan Kemahiran Teknologi Maklumat serta Komunikasi Guru Terhadap Prestasi Subjek Perniagaan Murid Sekolah Menengah
}

\author{
Kasturi Rajan', Norasmah Hj Othman' ${ }^{1}$ \\ ${ }^{1}$ Fakulti Pendidikan, Universiti Kebangsaan Malaysia (UKM), Malaysia \\ Correspondence: Kasturi Rajan (astu2317@gmail.com)
}

\begin{abstract}
Abstrak
Kajian ini dilaksanakan untuk melihat pengetahuan dan kemahiran teknologi maklumat dan komunikasi (TMK) guru terhadap prestasi subjek perniagaan murid sekolah menengah. Kaedah kuantitatif telah digunakan dalam kajian ini yang melibatkan pelajar tingkatan 4 sekolah menengah yang terletak di daerah Sepang. Seramai 265 orang pelajar yang mengambil mata pelajaran Perniagaan telah dipilih sebagai sampel kajian. Hasil analisis deskriptif mendapati bahawa guru menunjukkan kesediaan TMK yang tinggi bagi aspek pengetahuan dan kemahiran. Seterusnya, hasil analisis inferensi menunjukkan terdapat hubungan yang signifikan bagi pengetahuan dan kemahiran TMK guru dengan pencapaian akademik pelajar. Secara keseluruhannya, kajian ini diharapkan akan dapat membantu pihak yang berkaitan dalam usaha mencipta kecemerlangan kualiti pendidikan bagi pelajar sekolah.
\end{abstract}

Kata kunci: pengetahuan, kemahiran, teknologi maklumat dan komunikasi

\section{Knowledge and Skills of Information and Communication Technology among Teachers on the Performance of Business Subjects of Secondary School Students}

\begin{abstract}
This study was conducted to identify the knowledge and skills of Information and Communication Technology (ICT) among teachers on the performance of business subjects of secondary school students. This study was a descriptive study of quantitative which involved form 4 secondary school students located in the district of Sepang. A total of 265 students who took Business subjects were selected as the study sample. The results of the descriptive analysis found that teachers showed a high readiness of ICT in terms of knowledge and skills of ICT. Furthermore, the results of inferential analysis show that there is a significant relationship for teachers ICT knowledge and skills with students academic achievement. Overall, this study is expected to help the relevant parties in creating excellence in the quality of education for school students.
\end{abstract}

Keywords: knowledge, skills, ICT 


\section{Pengenalan}

Guru pada masa kini tidak dapat menjangka sama ada pelajar bersedia atau tidak jika proses pengajaran dan pembelajaran dilaksanakan dengan menggunakan teknologi pendidikan. Ini kerana guru sendiri dilaporkan belum sepenuhnya memiliki persediaan yang mencukupi untuk menggunakan teknologi pendidikan dalam proses pengajaran dan pembelajaran (Kimmons, Graham, \& West, 2020). Tambahan pula, dengan arus teknologi pendidikan yang sentiasa berubah-berubah ini menyebabkan keadaan menjadi bertambah sukar untuk guru mengenal pasti proses pengajaran dan pembelajaran yang benar-benar sesuai. Bagaimanapun apa yang jelas adalah proses pengajaran dan pembelajaran tradisional memang tidak lagi sesuai digunakan sepenuh dalam dunia pendidikan masa kini (Ghavifekr et al., 2016).

Terkini, teknologi berperanan penting dalam dunia pendidikan. Rentetan itu, para guru perlu memiliki pengetahuan dan kemahiran Teknologi Maklumat Dan Komunikasi (TMK) agar perubahan dalam sistem pendidikan dapat disahut oleh mereka. Kompetensi guru sama ada dari aspek ilmu pengetahuan dan kemahiran berkaitan TMK boleh membantu minat dan tingkah laku mereka terhadap subjek yang diajari, dalam hal ini adalah subjek Perniagaan (Gupta \& Pathania, 2020). Keberkesanan teknologi dalam bidang pendidikan bergantung kepada sikap guru terhadap teknologi serta kemahiran teknologi pembelajaran yang digunakan oleh seorang guru (Polly et al., 2020). Pendekatan pengajaran yang menggunakan teknologi bergantung kepada kurikulum dan jenis teknologi yang digunakan oleh guru semasa proses pengajaran dan pembelajaran (Jung \& Ottenbreit-Leftwich, 2020). Ini jelas menunjukkan bahawa guru memainkan peranan penting terhadap proses pengajaran dan pembelajaran kerana persepsi guru terhadap penggunaan teknologi dalam bidang pendidikan akan mempengaruhi proses pengajaran dan pembelajaran secara langsung (Taat \& Francis, 2020).

Pada masa yang sama, terdapat juga cabaran dalam menggunakan TMK untuk pendidikan. Ini disebabkan sistem teknologi yang sentiasa berubah-berubah (Knezek, Christensen, \& Furuta, 2019). Menurut Kementerian Pendidikan Malaysia (2013), hanya 80\% guru sahaja yang menggunakan TMK kurang satu jam seminggu. Kementerian juga mendapati melalui laporan murid di sekolah bahawa tidak ramai guru yang mengaplikasikan TMK secara konsisten dalam sesi pengajaran dan pembelajaran mereka (Kementerian Pendidikan Malaysia, 2013). Perkara ini amat mengecewakan walaupun pelbagai program latihan TMK telah disediakan khususnya untuk para guru. Ini kerana, kewujudan pelbagai teknologi untuk digunakan dalam pengajaran dan pembelajaran menyebabkan guru sukar untuk memahami kesemuanya sehingga mereka tidak pasti dengan kaedah yang bersesuaian untuk sesuatu proses pengajaran dan pembelajaran (Strycker, 2020).

Acapkali, guru mengalami masalah ketidakseimbangan apabila mengubah kaedah mengajar tradisional kepada penggunaan teknologi kerana keberkesanan teknologi bergantung kepada kepercayaan guru terhadap teknologi yang digunakan semasa proses pengajaran dan pembelajaran (Cheung, 2021). Oleh sebab itu, terdapat keperluan untuk melaksanakan kajian yang bertujuan mengenal pasti: 1) Tahap pengetahuan TMK dalam kalangan guru 3) Kemahiran TMK dalam kalangan para guru 2) Menguji hubungan antara kesediaan TMK (Pengetahuan dan kemahiran) guru dengan prestasi pelajar dalam subjek perniagaan.

\section{Sorotan Literatur}

\section{Pengetahuan TMK Guru}

Habib (2005) melaporkan kajian kuantitatif mengenai kesediaan guru dari segi pengetahuan TMK guru sekolah menengah terhadap pelaksanaan perubahan. Hasilnya membuktikan sebanyak $20.8 \%$ guru bersedia untuk menerima dan melaksanakan perubahan di sekolah sementara $19.9 \%$ guru tidak bersedia dan 59.3\% yang lain adalah kurang bersedia. Dapatan kajian turut memperjelaskan bahawa reaksi guru dalam menerima dan melaksanakan sesuatu perubahan kurikulum sekolah adalah tidak meluas. Perkara ini harus dipandang serius kerana tahap pengetahuan guru dalam menggunakan TMK 
adalah sesuatu yang penting dan harus diberikan penekanan (Siti Fatimah \& Ab. Halim, 2010). Ini kerana, guru perlu berupaya menguasai pengetahuan TMK yang diperlukan untuk disampaikan kepada pelajar supaya dapat memupuk keupayaan pemprosesan maklumat supaya pelajar akan dapat membina sendiri pengetahuan dan pembelajaran.

Ini kerana, pelajar akan memahami dengan lebih jelas tentang perkara yang diajar serta dapat mengaitkan segala maklumat yang diperolehi dan memahami subjek tersebut. Kajian turut menunjukkan hanya segelintir kumpulan guru berpengetahuan dalam asas TMK. Majoriti mereka hanya mempunyai pengetahuan sederhana dalam TMK atau pengetahuan TMK yang sangat minima (Mahmud et al., 2012). Keadaan ini jelas menunjukkan bahawa faktor utama dalam membuat program yang berkaitan dengan TMK berjaya di sekolah adalah dengan meningkatkan tahap pengetahuan TMK dalam kalangan guru (Moganashwari \& Parilah, 2013). Ini seiring dengan kerangka pembangunan kerajaan bagi melahirkan masyarakat yang berpengetahuan TMK.

\section{Kemahiran TMK Guru}

Dari segi kemahiran dalam kaedah pengajaran dan pembelajaran, kajian mendapati majoriti guru lebih selesa menggunakan kaedah konvensional dalam pengajaran kerana mereka sudah sebati dengan kaedah tersebut (Habib, 2005). Tambahan pula, penguasaan guru dalam penggunaan komputer dalam proses pengajaran dan pembelajaran juga kurang memberangsangkan disebabkan oleh infrastruktur. Hal ini selari dengan kenyataan Kementerian Pelajaran Malaysia (2001) bahawa sekolah-sekolah di luar bandar menghadapi masalah kekurangan kemudahan berbanding di bandar dan kekurangan kemudahan ini boleh menjadi faktor penghalang kepada usaha pelaksanaan perubahan kurikulum secara berkesan.

Kecekapan guru dalam teknologi digital dan teknologi maklumat mempunyai hala tuju yang sama kerana kedua-dua kompetensi ini memerlukan guru berkemahiran serta berfikiran kritis dan kreatif dalam memanfaatkan penggunaan Teknologi Maklumat Dan Komunikasi (Svensson \& Baelo, 2015). Tambahan pula, prasyarat penting untuk menguasai kemahiran ICT oleh guru ialah dengan cara berupaya untuk menggunakan teknologi komputer, memudahkan penggunaan teknologi pendidikan dan bahan digital dalam sistem pendidikan (Wakefield, 2015). Tambahan pula, dari sudut pelajar pula penggunaan digital dalam proses pengajaran dan pembelajaran mampu memberikan faedah yang terbaik kerana bahan yang disepadukan dengan teknologi maklumat lebih pantas dan mudah diterima oleh pelajar (Ramirez, Mena \& Arroyo, 2017). Selain itu, pendekatan penggunaan TMK dalam proses pengajaran dan pembelajaran mampu membina pengetahuan pelajar dengan prinsip pembelajaran bebas dan teknologi maklumat pembelajaran dilihat sebagai satu bentuk pendidikan sepanjang hayat kerana ia dilihat sebagai satu bentuk pembelajaran yang boleh dilakukan di mana-mana dan di bilabila masa tanpa batasan ruang dan masa (Rokenes \& Krumsvik, 2016).

\section{Kesediaan Penggunaan TMK Dalam Kalangan Guru}

Kajian bagi mengukur tahap kesediaan penggunaan TMK asas dalam kalangan guru di Malaysia telah dilakukan oleh Rosnaini (2006) dengan menggunakan pendekatan yang digunakan oleh Wong (2002). Ketiga-tiga aspek kesediaan penggunaan TMK iaitu pengetahuan, kemahiran dan sikap terhadap TMK dikaji secara serentak. Kajian ini adalah berbentuk tinjauan dengan menggunakan set instrumen ujian objektif empat pilihan jawapan sebanyak 20 soalan bagi mengukur pengetahuan menggunakan TMK dan set ujian kemahiran menggunakan TMK yang perlu dilakukan secara amali.

Instrumen soal selidik yang dibina Rosnaini (2006) terdiri daripada 44 item bagi mengukur sikap guru terhadap TMK berdasarkan empat aspek kegunaan, keyakinan, kebimbangan dan keengganan. Dapatan kajian menunjukkan kebanyakan guru mempunyai sikap positif terhadap TMK tetapi masih tidak mempunyai pengetahuan dan kemahiran asas TMK yang mendalam. Kajian ini turut mendapati bahawa pengetahuan dan kemahiran TMK guru masih berada pada tahap sederhana sahaja. Kajian turut mendapati hubungan yang signifikan antara pengetahuan, kemahiran, sikap dan pencapaian TMK. 
Kesediaan seorang guru untuk menyesuaikan diri bagi menggunakan teknologi pendidikan dalam aktiviti profesional dan pedagogi berkait rapat dengan motivasi pelajar mengenai pengetahuan tentang asas teori teknologi pendidikan, reka bentuk dan pelaksanaannya dalam aktiviti profesional pedagogi serta keupayaan untuk melaksanakan refleksi (Vaganova, 2019). Pada masa yang sama, pembangunan dan penggunaan teknologi interaktif membantu meningkatkan kadar pemerolehan bahan pengajaran kepada seorang guru (Petrichev, 2018). Teknologi pendidikan ini turut difahamkan sebagai proses interaksi tersusun secara sosial antara pelajar dan guru bertujuan untuk mencapai hasil yang dirancang (Kobernyk, 2018).

\section{Metod Kajian}

\section{Reka Bentuk Kajian}

Kajian ini adalah kajian deskriptif kuantitatif yang berbentuk tinjauan dengan menggunakan soal selidik sebagai instrumen kajian. Kaedah kuantitatif telah digunakan dalam kajian ini untuk tujuan menguji hipotesis, menjawab persoalan kajian serta mengkaji hubungan antara pemboleh ubah kajian.

\section{Lokasi Kajian}

Kajian ini telah dilaksanakan di sekolah menengah yang melibatkan pelajar tingkatan 4 di daerah Sepang. Pemilihan daerah Sepang daripada negeri Selangor sebagai lokasi kajian adalah kerana negeri Selangor merupakan negeri yang mempunyai jumlah sekolah menengah kedua tertinggi iaitu sebanyak 270 buah sekolah selepas negeri Johor iaitu 276 buah sekolah (Kementerian Pendidikan Malaysia 2019a). Pemilihan daerah Sepang sebagai kumpulan sasaran pula adalah disebabkan bilangan pelajar yang mengambil subjek perniagaan dalam daerah ini adalah kedua tertinggi selepas daerah Petaling Perdana berbanding dengan daerah-daerah yang lain (JPN Selangor, 2021).

\section{Populasi dan Persampelan Kajian}

Data yang diperolehi dari Pejabat Pendidikan Daerah (PPD) Sepang menunjukkan terdapat 13 buah sekolah dalam daerah Sepang, Selangor. Disebabkan skop kajian adalah menjurus ke arah mata pelajaran perniagaan, bermakna ia hanya melibatkan pelajar menengah atas. Untuk kajian ini, kumpulan sasaran hanya memfokuskan kepada pelajar Tingkatan 4 yang mengambil subjek Perniagaan dan pelajar Tingkatan 5 tidak dilibatkan kerana mereka akan berdepan dengan Sijil Peperiksaan Malaysia (SPM). Justeru, jumlah populasi (pelajar tingkatan 4) adalah seramai 849 orang (Pejabat Pendidikan Daerah Sepang, 2021). Berdasarkan jumlah populasi tersebut, hanya seramai 265 orang sahaja dilibatkan dalam kajian. Penentuan saiz sampel ini diperoleh dengan menggunakan Jadual Krejcie dan Morgan (1970) sebagai panduan. Sampel juga dipilih secara rawak mudah.

\section{Instrumen Kajian}

Kajian ini menggunakan soal selidik sebagai instrumen kajian. Borang soal selidik ini mengandungi tiga bahagian iaitu Bahagian A (Maklumat Responden), Bahagian B (Pengetahuan Penggunaan TMK) dan Bahagian C (Kemahiran TMK) yang perlu dilengkapkan oleh sampel kajian. Pembinaan item soal selidik kajian ini telah diadaptasi daripada kajian-kajian lepas.

Bahagian A bertujuan untuk mendapatkan maklumat berkaitan latar belakang sampel seperti umur, bangsa, jantina dan keputusan akademik mata pelajaran perniagaan. Bahagian B adalah mengenai pengetahuan TMK Guru. Bahagian ini mengandungi 7 item untuk mengukur fakta dan pemahaman guru mengenai TMK. Instrumen ini diadaptasi dan diubahsuai dari kajian Johari et al. (2014); Mamat et al. (2021); Rinaldi (2017); Chung (2010). Terdapat empat item menganalisis tahap pengetahuan guru dari segi fakta yang terdiri daripada item B1, B2, B3, dan B4 dan tiga item menganalisis dari segi pemahaman yang terdiri daripada item B5, B6 dan B7. Bahagian C pula mengukur mengenai kemahiran penggunaan TMK Guru. Terdapat dua sub-konstruk di bahagian ini iaitu kemahiran persembahan elektronik (Presentation) dan Internet. 


\section{Tatacara Penganalisisan Data}

Bagi kajian ini, data telah dianalisis dengan menggunakan perisian SPSS versi 25.0. Analisis deskriptif telah dilakukan bagi menjawab objektif kajian yang pertama dan kedua dengan membandingkan skor min aspek pengetahuan, kemahiran dan sikap. Tahap interpretasinya adalah seperti di Jadual 1.

Jadual 1: Jadual interpretasi skor min

\begin{tabular}{cc}
\hline Skala Min & Interpretasi \\
\hline $1.00-2.00$ & Rendah \\
$2.01-3.00$ & Sederhana Rendah \\
$3.01-4.00$ & Sederhana Tinggi \\
$4.01-5.00$ & Tinggi \\
\hline
\end{tabular}

Sumber: Nunally (1994)

Penganalisisan data diteruskan menerusi analisis inferensi yang digunakan bagi menjawab objektif kajian yang ketiga ialah Korelasi Spearman Rho. Korelasi ini digunakan untuk menguji hubungan antara dua pemboleh ubah. Menurut Chua (2006), statistik korelasi digunakan untuk mengukur sama ada wujud hubungan signifikan atau tidak. Dalam kajian ini, korelasi akan digunakan untuk menganalisis hubungan kesediaan TMK (Pengetahuan dan Kemahiran) guru dengan peningkatan prestasi subjek perniagaan pelajar sekolah menengah.

\section{Hasil Kajian}

\section{Demografi Kajian}

Seramai 265 orang responden telah mengambil bahagian dalam kajian ini, yang terdiri daripada pelajar berumur 16 tahun dan 17 tahun. Seramai 187 orang daripada bilangan tersebut merupakan responden perempuan (70.6\%), manakala 78 orang merupakan responden lelaki (29.4\%) (Jadual 2).

Jadual 2: Maklumat latar belakang responden

\begin{tabular}{llll}
\hline Demografi & Prekuensi & $\begin{array}{l}\text { Peratus } \\
\mathbf{0}=\mathbf{2 6 5}\end{array}$ \\
\hline Umur & 16 & 261 & 98.5 \\
& 17 & 4 & 1.5 \\
Jantina & Lelaki & 78 & 29.4 \\
& Perempuan & 187 & 70.6 \\
Etnik & Melayu & 121 & 45.7 \\
& Cina & 69 & 26.0 \\
& India & 43 & 16.2 \\
& Lain - lain & 32 & 12.1 \\
Markah subjek & G (0 - 39) & 1 & \\
Perniagaan & E (40 - 44) & 4 & 0.4 \\
& D (45 - 49) & 1 & 1.5 \\
& C (50 - 54) & 6 & 0.4 \\
& C $(55-59)$ & 16 & 2.3 \\
& &
\end{tabular}


DOI: https://doi.org/10.47405/mjssh.v7i1.1251

\begin{tabular}{llll}
\hline & B $(60-64)$ & 30 & 11.3 \\
& B+ $(65-69)$ & 69 & 26.0 \\
A- $(70-79)$ & 80 & 30.2 \\
A $(80-89)$ & 48 & 18.1 \\
& A+ $(90-100)$ & 10 & 3.8 \\
Tahap & Cemerlang & 138 & 52.1 \\
& Kepujian & 121 & 45.7 \\
& Lulus & 5 & 1.9 \\
Gagal & 1 & 0.4 \\
Minat terhadap subjek & Ya & 257 & 97.0 \\
Perniagaan & Tidak & 8 & 3.0 \\
& & & \\
\hline
\end{tabular}

Dari segi kumpulan etnik pula, $45.7 \%$ daripada responden adalah berbangsa Melayu, diikuti dengan bangsa Cina (26.0\%), bangsa India (16.2\%), dan lain-lain bangsa yang terdiri daripada bangsa Orang Asli dan Sikh (12.1\%). Dari aspek markah subjek perniagaan pula, sebilangan besar responden memperoleh gred A- iaitu seramai 80 orang dengan memperoleh skor di antara 70 ke $79(30.2 \%)$, diikuti dengan gred B+ seramai 69 orang $(26.0 \%)$, gred A sebanyak 48 orang $(18.1 \%)$, gred B seramai 30 orang $(11.3 \%)$ dan selebihnya setiap satu kurang daripada 20 orang. Bagaimanapun seorang responden telah mendapat gred G iaitu gagal. Maklumat perinci boleh dirujuk pada Jadual 2.

Dari aspek minat terhadap subjek perniagaan pula, data menunjukkan daripada 265 orang murid, hanya 8 orang sahaja tidak berminat (3\%). Ini bermakna majoriti murid memang mempunyai minat terhadap subjek Perniagaan iaitu seramai 257 orang atau bersamaan 97.0\%. Dari segi pencapaian prestasi subjek Perniagaan, seramai 138 iaitu 52.1\% orang responden berada pada tahap cemerlang iaitu di antara skor 70-100 diikuti dengan 121 iaitu 45.7\% responden berada pada tahap kepujian di antara skor 50-69. Seramai lima orang responden bersamaan dengan $1.9 \%$ berada dalam tahap lulus dengan skor di antara 40-49 dan satu responden iaitu 0.4\% memperoleh keputusan gagal dengan skor di antara 0-39.

\section{Tahap Pengetahuan (Fakta dan Pemahaman) TMK Guru Sekolah Menengah}

Berdasarkan data yang diperolehi daripada responden, keseluruhan analisis menunjukkan tahap pengetahuan penggunaan TMK guru sekolah menengah berada pada tahap tinggi dengan purata min sebanyak 4.26 dan nilai sisihan piawai sebanyak 0.27. Empat item dianalisis bagi mengenal pasti tahap pengetahuan guru dari segi fakta yang terdiri daripada item B1, B2, B3, dan B4. Setiap item ditanda dengan skala yang menunjukkan kekerapan dan peratus yang berbeza-beza dan skala setuju merupakan skala yang mendapat nilai peratusan yang tertinggi berbanding skala-skala lain. Item B1 menunjukkan peratusan setuju yang paling tertinggi di mana 'Guru nampak berpengetahuan tentang bidang yang berkaitan dengan reka bentuk pengajaran berkomputer' dengan peratusan sebanyak 88.7 peratus ( $\mathrm{S}=45.1$ peratus dan $\mathrm{SS}=43.6$ peratus) (Jadual 3). Ini menunjukkan ramai guru yang mengajar subjek perniagaan mempunyai pengetahuan yang mendalam bagi mencari maklumat dan bahan-bahan yang berkaitan dengan proses pengajaran dan pembelajaran.

Item kedua yang menunjukkan peratus setuju yang tinggi bagi aspek fakta TMK guru ialah item B3 'Guru berpengetahuan tentang penggunaan komputer untuk mencari bahan bantu mengajar perniagaan dengan cepat dan efektif (Contohnya: internet)' dengan peratusan persetujuan sebanyak 85.7 peratus ( $\mathrm{S}=48.1$ peratus dan $\mathrm{SS}=37.6$ peratus). Peratusan persetujuan Item B1 dan B3 yang dianalisis dari aspek fakta telah menyumbang kepada purata min yang tinggi. Berdasarkan peratus setiap item, ia memang benar-benar menonjolkan bahawa tahap pengetahuan penggunaan Teknologi Maklumat dan Komunikasi (TMK) guru sekolah menengah daripada aspek pengetahuan dari segi fakta berada pada tahap yang tinggi. 
Bagi konstruk yang menganalisis tahap pengetahuan guru dari segi pemahaman terdiri daripada tiga item iaitu B5, B6 dan B7. Analisis per item menunjukkan, frekuensi yang paling ialah tertinggi ialah item $\mathrm{B} 7$ sebanyak 91 peratus $(\mathrm{S}=30.1$ peratus dan $\mathrm{SS}=60.9)$ iaitu 'Guru mahir menggunakan komputer semasa proses PdPc bagi mata pelajaran perniagaan'. Item kedua yang mempunyai persetujuan yang tertinggi ialah item B6 iaitu 'Pengetahuan TMK guru saya dapat memantapkan lagi proses pembelajaran mata pelajaran perniagaan' iaitu sebanyak 83.5 peratus ( $\mathrm{S}=42.1$ peratus dan $\mathrm{SS}=41$ peratus). Namun begitu, item B6 mencatatkan peratusan yang paling rendah iaitu sebanyak 82.1 peratus ( $\mathrm{S}=42.1$ peratus dan $\mathrm{SS}=41$ peratus) dengan penyataan 'Guru saya boleh menggunakan laman sosial untuk berkongsi maklumat mengenai mata pelajaran perniagaan'. Analisis dapatan ini menunjukkan bahawa tahap pengetahuan penggunaan Teknologi Maklumat dan Komunikasi (TMK) guru sekolah menengah daripada aspek pengetahuan dari segi fakta dan pemahaman berada pada tahap yang tinggi dengan nilai min keseluruhan sebanyak 4.26.

Jadual 3: Pengetahuan (Fakta dan Pemahaman) TMK Guru

\begin{tabular}{|c|c|c|c|c|c|c|c|c|c|c|c|}
\hline \multirow{2}{*}{$\begin{array}{l}\text { No } \\
\text { Item }\end{array}$} & \multirow[t]{2}{*}{$n=265$} & \multicolumn{2}{|l|}{ ST } & \multicolumn{2}{|l|}{ TS } & \multicolumn{2}{|l|}{ KS } & \multicolumn{2}{|l|}{$\mathbf{S}$} & \multicolumn{2}{|l|}{ SS } \\
\hline & & $\begin{array}{l}\text { S } \\
\text { Bil }\end{array}$ & $\%$ & Bil & $\%$ & Bil & $\%$ & Bil & $\%$ & Bil & $\%$ \\
\hline B1 & $\begin{array}{l}\text { Guru nampak berpengetahuan tentang } \\
\text { bidang yang berkaitan dengan reka } \\
\text { bentuk pengajaran berkomputer. }\end{array}$ & 1 & 0 & 5 & 1.9 & 25 & 9.4 & 120 & 45.1 & 116 & 43.6 \\
\hline B2 & $\begin{array}{l}\text { Guru berpengetahuan tentang } \\
\text { penggunaan aplikasi Pembelajaran } \\
\text { Berbentukan Komputer semasa proses } \\
\text { PdPc mata pelajaran perniagaan. }\end{array}$ & 1 & 0.4 & 3 & 1.1 & 35 & 13.2 & 111 & 41.7 & 116 & 43.6 \\
\hline B3 & $\begin{array}{l}\text { Guru berpengetahuan tentang } \\
\text { penggunaan komputer untuk mencari } \\
\text { bahan bantu mengajar perniagaan } \\
\text { dengan cepat dan efektif (Contohnya: } \\
\text { internet). }\end{array}$ & 1 & 0.4 & 8 & 3 & 29 & 10.9 & 128 & 48.1 & 100 & 37.6 \\
\hline B4 & $\begin{array}{l}\text { Guru berpengetahuan tentang cara-cara } \\
\text { berkomunikasi yang berkaitan dengan } \\
\text { aplikasi bagi mata pelajaran perniagaan } \\
\text { (Contoh: e-mail, Zoom, Teams). }\end{array}$ & 1 & 0.4 & 3 & 1.1 & 39 & 14.7 & 111 & 41.7 & 112 & 42.1 \\
\hline B5 & $\begin{array}{l}\text { Guru saya boleh menggunakan laman } \\
\text { sosial untuk berkongsi maklumat } \\
\text { mengenai mata pelajaran perniagaan. }\end{array}$ & 1 & 0.4 & 8 & 3 & 36 & 13.5 & 112 & 42.1 & 109 & 41 \\
\hline B6 & $\begin{array}{l}\text { Pengetahuan TMK guru saya dapat } \\
\text { memantapkan lagi proses pembelajaran } \\
\text { mata pelajaran perniagaan. }\end{array}$ & 4 & 1.5 & 6 & 2.3 & 34 & 12.8 & 133 & 50 & 89 & 33.5 \\
\hline B7 & $\begin{array}{l}\text { Guru mahir menggunakan komputer } \\
\text { semasa proses PdPc bagi mata pelajaran } \\
\text { perniagaan. }\end{array}$ & 2 & 0.8 & 6 & 2.3 & 16 & 6 & 80 & 30.1 & 162 & 60.9 \\
\hline
\end{tabular}

Nota: Purata Min $=4.26 ;$ Sisihan Piawai $=0.27$; Tahap $=$ Tinggi

\section{Tahap Kemahiran (Persembahan Elektronik dan Internet) TMK Guru}

Bagi menjawab persoalan kajian yang kedua terdapat dua konstruk kemahiran yang diukur iaitu dari segi kemahiran persembahan elektronik (Presentation) dan Internet. Bahagian ini mengandungi 7 item iaitu item $\mathrm{C} 1, \mathrm{C} 2, \mathrm{C} 3$ dan $\mathrm{C} 4$ untuk kemahiran persembahan elektronik (Presentation) dan item C5, C6 DAN C7 untuk Internet. Item C1 menunjukkan peratusan setuju yang paling tertinggi di mana 'Guru selalu menggunakan perisian Microsoft PowerPoint untuk membuat persembahan elektronik mengenai subjek perniagaan' dengan peratusan sebanyak 80 peratus $(\mathrm{S}=47.9$ peratus dan $\mathrm{SS}=32.1$ peratus). Item kedua yang menunjukkan peratus setuju yang tinggi bagi aspek kemahiran persembahan elektronik (Presentation) ialah item C3 'Guru saya mahir membina persembahan slaid interaktif dengan menggunakan penggunaan grafik dan bunyi semasa PdPc subjek perniagaan' ialah sebanyak 85.5 peratus $(\mathrm{S}=47.9$ peratus dan $\mathrm{SS}=37.6$ peratus) diikuti dengan item C2 iaitu 'Guru saya mendapati perisian persembahan elektronik Microsoft PowerPoint memudahkan proses pembelajaran subjek perniagaan' dengan peratus persetujuan sebanyak 79.7 peratus $(\mathrm{S}=46.6$ peratus dan $\mathrm{SS}=33.1$ peratus). 
Bagi konstruk yang menganalisis tahap kemahiran guru dari aspek internet terdiri daripada empat konstruk iaitu C4, C5, C6 dan C7. Di mana, analisis per item menunjukkan, frekuensi yang paling tinggi ialah item $\mathrm{C} 7$ iaitu 'Guru saya mahir menggunakan multimedia yang interaktif bagi menjadikan PdPc subjek perniagaan lebih berkesan' iaitu sebanyak 83.4 peratus $(S=30.1$ peratus dan $S S=60.9)$. Item kedua yang menunjukkan peratus setuju yang tinggi ialah item C4 iaitu 'Guru selalu menggunakan Internet Explorer untuk mencari maklumat dari internet bagi subjek perniagaan' iaitu sebanyak $83.3(S=45.5$ peratus dan $\mathrm{SS}=36.8)$. Dapatan ini menunjukkan guru giat mencari bahan pengajaran daripada sumber internet. Secara keseluruhannya, dapatan kajian menunjukkan bahawa tahap kemahiran TMK guru sekolah menengah adalah tinggi kerana purata min mencatatkan nilai 4.15 .

Jadual 4: Frekuensi, skor, min dan sisihan piawai tahap kemahiran

\begin{tabular}{|c|c|c|c|c|c|c|c|c|c|c|c|}
\hline No & $n=265$ & STS & & TS & & KS & & S & & SS & \\
\hline Item & & Bil & $\%$ & Bil & $\%$ & Bil & $\%$ & Bil & $\%$ & Bil & $\%$ \\
\hline $\mathrm{C} 1$ & $\begin{array}{l}\text { Guru selalu menggunakan } \\
\text { perisian Microsoft PowerPoint } \\
\text { untuk membuat persembahan } \\
\text { elektronik mengenai subjek } \\
\text { perniagaan. }\end{array}$ & 1 & 0.4 & 10 & 3.8 & 42 & 15.8 & 127 & 47.9 & 85 & 32.1 \\
\hline $\mathrm{C} 2$ & $\begin{array}{l}\text { Guru saya mendapati perisian } \\
\text { persembahan elektronik } \\
\text { Microsoft PowerPoint } \\
\text { memudahkan proses } \\
\text { pembelajaran subjek } \\
\text { perniagaan. }\end{array}$ & 2 & 0.8 & 12 & 4.5 & 40 & 15 & 124 & 46.6 & 88 & 33.1 \\
\hline C3 & $\begin{array}{l}\text { Guru saya mahir membina } \\
\text { persembahan slaid interaktif } \\
\text { dengan menggunakan } \\
\text { penggunaan grafik dan bunyi } \\
\text { semasa PdPc subjek } \\
\text { perniagaan. }\end{array}$ & 3 & 1.1 & 2 & 0.8 & 33 & 12.5 & 126 & 47.9 & 99 & 37.6 \\
\hline $\mathrm{C} 4$ & $\begin{array}{l}\text { Guru selalu menggunakan } \\
\text { Internet Explorer untuk mencari } \\
\text { maklumat dari internet bagi } \\
\text { subjek perniagaan. }\end{array}$ & 1 & 0.4 & 3 & 1.1 & 43 & 16.2 & 121 & 45.5 & 98 & 36.8 \\
\hline $\mathrm{C} 5$ & $\begin{array}{l}\text { Guru selalu menggunakan } \\
\text { capaian laman sesawang } \\
\text { seluruh dunia bagi tujuan PdPc } \\
\text { subjek perniagaan. }\end{array}$ & 1 & 0.4 & 4 & 1.5 & 31 & 11.7 & 124 & 46.6 & 106 & 39.8 \\
\hline C6 & $\begin{array}{l}\text { Guru selalu berkongsi fail } \\
\text { elektronik mengenai subjek } \\
\text { perniagaan. }\end{array}$ & 3 & 1.1 & 5 & 1.9 & 50 & 18.8 & 113 & 42.5 & 95 & 35.7 \\
\hline C7 & $\begin{array}{l}\text { Guru saya mahir menggunakan } \\
\text { multimedia yang interaktif bagi } \\
\text { menjadikan PdPc subjek } \\
\text { perniagaan lebih berkesan. }\end{array}$ & 1 & 0.4 & 4 & 1.5 & 39 & 14.7 & 116 & 43.8 & 105 & 39.6 \\
\hline
\end{tabular}

Nota: Purata $\min =4.14 ;$ Sisihan Piawai $=0.49 ;$ Tahap $=$ Tinggi

\section{Pengetahuan dan Kemahiran Terhadap Peningkatan Prestasi Subjek Perniagaan Pelajar Sekolah Menengah}

Pengkaji telah menggunakan Ujian Korelasi Spearmen untuk melihat sama ada terdapat hubungan antara pengetahuan TMK dan prestasi subjek perniagaan serta hubungan antara kemahiran TMK dan prestasi subjek perniagaan. Ini kerana, Ujian Korelasi Spearman digunakan bagi mengenal pasti 
perhubungan antara dua variabel yang menggunakan skala ordinal sebagai skala pengukuran. Dalam konteks kajian ini, pemboleh ubah yang sesuai digunakan untuk analisis statistik korelasi Spearman ialah gred pencapaian akademik.

\section{H01: Terdapat hubungan yang signifikan antara pengetahuan TMK dan peningkatan prestasi subjek Perniagaan}

Jadual 5: Ujian Korelasi Spearmen antara pencapaian subjek Perniagaan dan pengetahuan TMK guru Sekolah Menengah

\begin{tabular}{ll}
\hline Pemboleh ubah & Nilai Pekali Korelasi \\
\hline Peningkatan prestasi subjek perniagaan & \multicolumn{1}{c}{$\mathrm{r}=0.322$} \\
Pengetahuan TMK guru & $\mathrm{Sig}=0.000$ \\
$\mathrm{n}=265$ \\
\hline
\end{tabular}

Jadual 5 menunjukkan ujian korelasi antara hubungan dengan pengetahuan TMK guru Sekolah Menengah dengan pencapaian prestasi subjek Perniagaan pelajar Sekolah Menengah dengan nilai korelasi $\mathrm{r}=0.322$. Hasil ujian menunjukkan hubungan positif pada kadar yang lemah dengan nilai $\mathrm{p}=$ 0.000 iaitu lebih kecil daripada aras keertian yang ditetapkan (Hussin et al., 2014). Nilai $\mathrm{P}<0.01$ adalah signifikan di mana wujud hubungan antara pengetahuan TMK guru dari segi fakta dan pemahaman aspek dengan pencapaian subjek perniagaan pelajar sekolah menengah. Oleh itu, hipotesis nol yang mengatakan terdapat hubungan yang signifikan antara pengetahuan TMK guru dengan pencapaian subjek perniagaan pelajar Sekolah Menengah diterima. Keputusan ini menjelaskan bahawa apabila tahap pengetahuan TMK guru meningkat, prestasi pencapaian bagi subjek Perniagaan juga akan bertambah baik.

\section{HO2: Terdapat hubungan yang signifikan antara kemahiran TMK dan Peningkatan prestasi Subjek Perniagaan}

Jadual 6 menunjukkan ujian korelasi antara Kemahiran TMK guru dengan peningkatan prestasi subjek perniagaan pelajar sekolah menengah dengan nilai korelasi $r=0.320$. Hasil ujian menunjukkan hubungan yang positif yang lemah dengan nilai $\mathrm{p}=0.000$ iaitu lebih kecil daripada aras signifikan yang ditetapkan (Hussin et al., 2014). Nilai $\mathrm{P}<0.01$ adalah signifikan di mana wujud hubungan antara Kemahiran TMK guru dengan peningkatan prestasi subjek perniagaan pelajar sekolah menengah. Oleh itu, hipotesis nul yang mengatakan terdapat hubungan yang signifikan antara kemahiran TMK dan pencapaian prestasi Subjek Perniagaan adalah gagal ditolak. Keputusan ini menjelaskan bahawa apabila tahap kemahiran TMK meningkat, prestasi pencapaian bagi subjek Perniagaan juga akan bertambah baik.

Jadual 6: Ujian Korelasi Spearman antara pencapaian subjek Perniagaan dan kemahiran TMK guru Sekolah Menengah

\begin{tabular}{ll}
\hline Pemboleh ubah & Nilai Pekali Korelasi \\
\hline Peningkatan prestasi subjek perniagaan & \multicolumn{1}{c}{$r=0.320$} \\
Kemahiran TMK guru & $\begin{array}{l}\text { Sig }=0.000 \\
\mathrm{n}=265\end{array}$ \\
\hline
\end{tabular}

\section{Perbincangan Kajian}

Secara keseluruhannya, dapatan kajian mendapati kesediaan guru subjek Perniagaan yang terdiri daripada pengetahuan dan kemahiran TMK guru berada pada tahap yang tinggi. Para pelajar mengakui bahawa guru mereka bersedia dari segi pengetahuan dan kemahiran dalam mengaplikasikan TMK dalam proses pengajaran dan pembelajaran subjek perniagaan. Kesediaan seseorang individu akan berubah jika ia dipengaruhi oleh tahap kesedaran individu tersebut (Vakola, 2013). Dalam aspek kajian ini, faktor yang mendorong kesediaan penggunaan TMK seseorang guru adalah dipengaruhi 
oleh kesedaran mereka yang tinggi. Kajian ini selaras dengan dapatan kajian Ismail (2013), yang menyatakan bahawa terdapat hubungan yang positif diantara tahap kesediaan guru terhadap penerimaan teknologi.

Dalam kajian ini, aspek pengetahuan penggunaan TMK guru terdiri daripada pengetahuan fakta dan pemahaman. Dapatan ini menyokong teori pemikiran kawalan adaptif bahawa pengetahuan fakta merupakan modal asas daripada pemahaman. Seseorang harus memiliki lebih banyak pengetahuan fakta sebelum menguasai pemahaman. Teori pemikiran kawalan Adaptif menyokong dapatan kajian ini bahawa pengetahuan fakta merupakan pengetahuan asas dari jenis pengetahuan deklaratif (Anderson, 1983). Ia boleh disimpan sebagai maklumat yang berasingan atau pun sebagai sebahagian maklumat yang dihubung kait secara konseptual antara satu sama lain. Kajian ini turut menyokong dapatan kajian Wetzel et al. (2014) bahawa untuk menggunakan teknologi, seseorang perlu tahu cara menggunakannya, memahami peranan dan kemampuan teknologi tersebut serta mengetahui tentang kaedah yang sesuai untuk mengintegrasikannya dalam pekerjaan.

Selain pengetahuan, kemahiran merupakan aspek lain yang penting. Dalam kajian ini, kemahiran TMK Guru turut berada pada tahap yang tinggi. Apabila dalam teori pemikiran kawalan adaptif pengetahuan fakta dan pemahaman dan aplikasi merupakan pengetahuan deklaratif. Maka, kemahiran adalah suatu pengetahuan cara kerja. Pengetahuan dan kerja merupakan pengetahuan mengenal bagaimana mengamalkan pengetahuan deklaratif. Dalam kajian ini, kemahiran TMK adalah bagi mengukur kemahiran persembahan elektronik dan Internet. Kemahiran internet dinilai daripada aspek kemahiran asas dalam mendapatkan maklumat dan menguruskan mel elektronik. Oleh itu, pengetahuan dan kemahiran merupakan dua unsur yang saling berkait rapat. Justeru, kedua-dua unsur tersebut harus dimiliki oleh seorang guru dan harus dikaji bersama-sama bagi mengenal pasti kesediaan TMK sebagaimana cadangan dalam kajian Wong (2002).

\section{Kesimpulan}

Secara keseluruhannya, kajian ini telah membincangkan dengan lebih jelas mengenai hasil kajian. Melalui kajian ini, permasalahan-permasalahan serta persoalan kajian boleh dijawab. Kajian ini adalah untuk menilai kesediaan TMK guru terhadap penggunaan TMK dalam meningkatkan prestasi subjek perniagaan pelajar sekolah menengah. Selain itu, kajian ini juga telah menjawab persoalan kajian berkenaan: (i) tahap pengetahuan penggunaan Teknologi Maklumat dan Komunikasi (TMK) guru sekolah menengah dari segi fakta dan pemahaman; (ii) tahap kemahiran dalam menggunakan TMK guru sekolah menengah ditinjau dari kemahiran persembahan elektronik (Presentation) dan internet (iii) hubungan antara pengetahuan dan kemahiran TMK guru terhadap peningkatan prestasi subjek perniagaan pelajar sekolah menengah. Hasil analisis inferensi menunjukkan terdapat hubungan yang signifikan bagi kesediaan TMK guru dengan pencapaian akademik pelajar. Kajian ini diharapkan akan dapat membantu pihak yang berkaitan dalam usaha mencipta kecemerlangan pelajar sekolah serta memberikan sumbangan baharu dimana penemuan tentang pengetahuan dan kemahiran guru.

\section{Rujukan}

Anderson, J.R. (1983). A spreading activation theory of memory. Journal of Verbal Learning and Verbal Behavior 22(3):261-295.

Cheung, A. (2021). Language teaching during a pandemic: A case study of zoom use by a secondary ESL teacher in Hong Kong. RELC Journal, 1-16. doi:10.1177/0033688220981784.

Chung, H. C. (2010). Sikap guru Bahasa Melayu terhadap penggunaan teknologi maklumat dan Komunikasi (ICT) dalam pengajaran di Sekolah-sekolah Rendah di Bintulu, Sarawak. Penerbit UKM. Gupta, A., \& Pathania, P. (2020). To study the impact of Google Classroom as a platform of learning and collaboration at the teacher education level. Education and Information Technologies, 26(1), 843-857. Doi: 10.1007/s10639-020-10294-1. 
Ghavifekr, S. \& Rosdy, W.A.W. (2015). Teaching and learning with technology: Effectiveness of ICT integration in schools. International Journal of Research in Education and Science (IJRES), 1(2), 175-191.

Ghavifekr, S., Kunjappan, T., Ramasamy, L. \& Anthony, A. (2016). Teaching and learning with TMK Tools: Issues and challenges from teachers' perceptions. Malaysian Online Journal of Educational Technology, 4(2), 38-57.

Habib Mat Som. (2005). Profil Kesediaan Guru Sekolah Menengah Terhadap Pelaksanaan Perubahan Kurikulum. Tesis PhD, Universiti Malaya.

Hussin, Fauzi \& Ali, Jamal \& Noor, Mohd. (2014). Kaedah penyelidikan \& analisis data SPSS. $10.32890 / 9789670474670$.

Ismail, I., Bokhare, S. F., Azizan, S. N., \& Azman, N. (2013). Teaching via Mobile Phone: A Case Study on Malaysian Teachers' Technology Acceptance and Readiness. Journal of Educators Online, 10(1), 1-38.Chua, Y.P. (2006). Kaedah Penyelidikan. Malaysia: McGraw-Hill Education.

Ifinedo, E., \& Kankaanranta, M. (2021). Understanding the influence of context in technology integration from teacher educators' perspective. Technology, Pedagogy and Education, 30(2), 1 15. doi:10.1080/1475939X.2020.1867231.

Joo, Y. J., Park, S., \& Lim, E. (2018). Factors influencing preservice teachers' intention to use technology: TPACK, teacher self-efficacy, and technology acceptance model. Journal of Educational Technology \& Society, 21(3), 48-59.

Jung, J., \& Ottenbreit-Leftwich, A. (2020). Course-level modeling of preservice teacher learning of technology integration. British Journal of Educational Technology. British Journal of Educational Technology, 51(2), 555-571. doi:10.1111/bjet.12840.

Kementerian Pendidikan Malaysia. (2013). Pelan Pembangunan Pendidikan Malaysia 2013-2025

(Pendidikan Prasekolah hingga Lepas Menengah). Putrajaya: Kementerian Pendidikan Malaysia. Retrieved from https://www.moe.gov.my/index.php/dasarmenu/pelan-pembangunan-pendidikan2013-2025.

Kementerian Pendidikan Malaysia. (2020, July 31). Statistic Of School, Student \& Teachers. Retrieved from MOE: https://www.moe.gov.my/en/statistik-menu/statistik-bilangan-sekolahmurid-guru.

Kimmons, R., Graham, C. R., \& West, R. E. (2020). The PICRAT model for technology integration in teacher preparation. Contemporary Issues in Technology and Teacher Education, 20(1), 176-198.

Knezek, G., Christensen, R., \& Furuta, T. (2019). Validation of a teacher educator technology competencies survey. Journal of Technology and Teacher Education, 27(4), 465-498.

Kementerian Pelajaran Malaysia. (2001). Pembangunan pendidikan 2001-2010. Perancangan bersepadu penjana kecemerlangan pendidikan.Putrajaya: Bahagian Pengurusan, Perancangan dan Dasar Pendidikan, KPM.

Krejcie, R.V. \& Morgan, D.W. (1970). Determining Sample Size for Research Activities. Educational and Psychological Measurement. 30(3):607-610.

Li, Y., Garza, V., Keicher, A., \& Popov, V. (2019). Predicting high school teacher use of technology: Pedagogical beliefs, technological beliefs and attitudes, and teacher training. Technology, Knowledge and Learning, 24(3), 501-518. doi:10.1007/s10758-018-9355-2.

Mamat, S.., Ladin, C. A. ., Kamaruddin, A. Y.., Omar, I. M. ., \& Ismail, N. A... (2021). Covid-19: Cabaran dan Inisiatif dalam Mendepani Pelaksanaan Pengajaran dan Pembelajaran Teradun. Jurnal Sains Insani, USM, 6(2). https://doi.org/10.33102/sainsinsani.vol6no2.319.

Mahmud, Rosnaini \& Ismail, Mohd \& Ahmad, Siti \& Rahman, Fadzilah \& Kamarudin, Nurzatulshima. (2012). Effectiveness of Integrating Eduwebtv Resources on Form Two Students' Achievement in Learning Science. Procedia - Social and Behavioral Sciences. 64. 161-168. 10.1016/j.sbspro.2012.11.019.

Moganashwari, K., \& Parilah, M. S. (2013). Knowledge, Attitude and Use of ICT among ESL Teachers. Proceeding of the Global Summit on Education. 11-12 March 2013, Kuala Lumpur. Organized by WorldConferences.net.

Nesbit, C. John \& Adesope, Olusola O. (2006). Learning with concept and knowledge maps: A Meta analysis. Review of Educational Research 76(3): 413-448.

Omar, M. K., Zahar, F. N., \& Rashid, A. M. (2020). Knowledge, skills, and attitudes as predictors in determining teachers' competency in Malaysian TVET institutions. Universal Journal of Educational Research, 8(3c), 95-104. doi:10.13189/ujer.2020.081612. 
Petrichev, P. V., Masyuk, N. N., Bushueva, M. A. (2018). Method of estimation of the effectiveness of the partnership Russian universities with foreign educational organizations, Azimut nauchnykh issledovaniy (Azimuth of Scientific Researches: Economics and Management), 7, 3 (24), 229-232.

Polly, D., Byker, E. J., Putman, S. M., \& Handler, L. K. (2020). Preparing elementary education teacher candidates to teach with technology: The role of modeling. Journal of Digital Learning in Teacher Education, 36(4), 250-265. doi:10.1080/21532974.2020.1795953.

Ramírez-Montoya, M. S., Mena, J., \& Rodríguez-Arroyo, J. A. (2017). In-service teachers' selfperceptions of digital competence and OER use as determined by a xMOOC training course. Computers in Human Behavior, 77, 356-364. http://doi.org/10.1016/j.chb.2017.09.010.

Røkenes, F. M., \& Krumsvik, R. J. (2016). Prepared to teach ESL with ICT? A study of digital competence in Norwegian teacher education. Computers and Education, 97, 1-20. http://doi.org/10.1016/j.compedu.2016.02.014.

Rinaldi. (2017).Kesediaan dan pencapaian akademik pelajar pengajian tinggi Islam di Sumatera Barat terhadap Teknologi Maklumat Dan Komunikasi (Thesis Doktor Falsafah). Fakulti Pendidikan Universiti Kebangsaan Malaysia.

Rosnaini Mahmud. (2006). Kesediaan teknologi maklumat dan komunikasi asas dalam pendidikan (TMKP) guru-guru sekolah menengah. Tesis Dr. Fal. Universiti Kebangsaan Malaysia.

Siti Fatimah Ahmad, and Ab. Halim Tamuri. (2010). Persepsi guru terhadap penggunaan bahan bantu mengajar berasaskan teknologi multimedia dalam pengajaran j-QAF. JIAE: Journal of Islamic and Arabic Education, 2 (2). pp. 53-64. ISSN 1985-6236.

Siti Hajar Halili, \& Suguneswary. (2016). Penerimaan Guru Terhadap Penggunaan Teknologi Maklumat dan Komunikasi Berasaskan Model TAM Dalam Pengajaran Mata Pelajaran Bahasa Tamil. Jurnal Kurikulum \& Pengajaran Asia Pasifik, 4(2), 31-41.

Strycker, J. (2020). K-12 art teacher technology use and preparation. Heliyon, 6(7), 1-12. DOI: 10.1016/ j.heliyon.2020.e04358.

Surif, J., Ibrahim, N. H., \& Abu Hassan, R. (2014). Tahap Amalan dan Pengintegrasian ICT dalam Proses Pengajaran dan Pembelajaran Sains. Sains Humanika, 2(4). https://doi.org/10.11113/sh.v2n4.463.

Svensson, M., \& Baelo, R. (2015). Teacher Students' Perceptions of their Digital Competence. Procedia-Social and Behavioral Sciences, 180 (November 2014), 1527-1534. Http: //doi.org/10.1016/ j.sbspro. 2015.02.302.

Taat, M. S., \& Francis, A. (2020). Factors Influencing the Students' Acceptance of E-Learning at Teacher Education Institute: An Exploratory Study in Malaysia. International Journal of Higher Education, 9(1), 133-141.

Vaganova, O.I., Smirnova, Z.V., Gruzdeva, M.L., Chaykina, Z.V., Ilyashenko, L.I. (2019d).

Development of training content for master students in course "mechatronics and robotics" at the University. Amazonia Investiga, 8 (22), $694-700$.

Vakola, M. (2013). Multilevel Readiness to Organizational Change: A Conceptual Approach. Journal of Change Management, 13(1), 96-109.

Wakefield, J. (2015). Teknologi di sekolah: Perubahan di masa depan di ruang kelas. Diperoleh dari http://www.bbc.com/news/technology-30814302?print=true.

Wetzel, James \& Potter, W. \& O'Toole, Dennis. (2014). The Influence of Learning and Teaching Styles on Student Attitudes and Achievement in the Introductory Economics Course: A Case Study. The Journal of Economic Education. 13. 33. 10.2307/1182869.

Wong Su Luan. (2002). Development and validation of an information Technology (IT) based instrument to measure teachers' IT preparedness. Tesis Dr. Fal. Universiti Putra Malaysia.

Wuryaningsih, W., Susilastuti, D., Darwin, M., \& Pierewan, A. (2019). Effects of Web-Based Learning and F2F Learning on Teachers Achievement in Teacher Training Program in Indonesia. International Joural of Emerging Technologies in Learning (IJET), 14(21), 123-147. doi:10.3991/ijet.v14i21.10736. 